\title{
Relationship Between Various Determinants and Dimensions of Financial Literacy Among Working Class
}

\author{
Khujan Singh ${ }^{1}$, Poonam Rani ${ }^{1} \&$ Chand Kiran ${ }^{1}$ \\ ${ }^{1}$ Haryana school of Business, Guru Jambheshwar University of Science and Technology, Hisar, India \\ Correspondence: Poonam Rani, Research Scholar, Haryana School of Business, Guru Jambheshwar University of \\ Science and Technology, Hisar 125001, India. E-mail: Poonam.dharyan@gmail.com
}

Received: April 23, 2020

Accepted: June 28, 2020

Online Published: October 4, 2020

doi:10.5430/ijfr.v11n5p319

URL: https://doi.org/10.5430/ijfr.v11n5p319

\begin{abstract}
The purpose of this empirical research work was to identify the relationship between various determinants of Financial Literacy among the working class of National Capital Region of India. It was a descriptive study based on the survey of 596 working class respondents. The data has been analyzed by factor analysis, correlation and regressions analysis. Based on the factor analysis, three factors have been found of financial knowledge, three factors of financial behaviour and in a similar manner four factors of financial attitude have been extracted. Further, based on the multiple regression models the contribution of financial attitude has been found highest in explaining the financial literacy and it has been followed by financial behaviour and financial knowledge. It means that both financial attitude and financial behaviour are better estimators of financial literacy in comparison to the financial knowledge. Therefore, the policy makers, financial system regulators and governments should do more efforts to improve the level of financial attitude and financial behaviour in comparison to the financial knowledge to improve the level of financial literacy because significant difference has been found in the level of financial attitude and financial behaviour across some of the demographic factors. The increased financial literacy would be helpful in improving the saving and investment behaviour of the public. This improved level of financial literacy of public will save the required level of capital for the capital formation for the targeted economic growth. Consequently, more employment opportunities will increase the social security in the society. Like every study, this study also have certain limitations like the universe of the study was limited to a particular geographical region i.e. National Capital Region of India, along with time and money constraints. In future similar study can be conducted by changing the target population and geographical area with a bigger sample.
\end{abstract}

Keywords: financial literacy, financial knowledge, financial behaviour, financial attitude

\section{Introduction}

Financial literacy includes awareness, knowledge about financial instruments and their application in business and personal life (Huston, 2010). But Vitt et al. (2000) defined the concept of financial literacy in simple words that it is an ability to read, understand the personal financial conditions that influences the individual wellbeing. Whereas, OECD (2005) has defined financial literacy as a combination of financial awareness, financial knowledge, skill, financial attitude and financial behaviour necessary to make sound financial decisions to achieve financial wellbeing of individual. Financial literacy includes the ability to determine financial choices, to manage money, saving and financial issues without any hesitation, ability to design future financial planning and to respond efficiently and competently against the actions that effect daily life financial decision.

\subsection{Statement of Problem and Objectives of the Study}

On the basis of review of literature, it has been found that there are very few studies available in which the relationship between the determinants of various dimension of financial literacy has been tested. The available studies have been conducted by targeting the graduate students and salary class but relatively with small sample size. There is one segment of the society i.e. working class which has not been so much taken up for study by the researchers and academicians particularly in India. Therefore, an endeavor has been made here to assess the relationship between the various determinants of financial knowledge, financial behaviour and financial attitude of working class of national capital region of India. Therefore, to make this effort successful two objectives have been set. These are: 
(i) To identify the factors that determines the level of financial literacy.

(ii) To assess the relationship between the various determinants and dimensions of financial literacy of the working class of National Capital Region of India.

1.1.1 To achieve the above mentioned objective, the following hypotheses have been formulated:

- $\mathrm{H}_{01}$ : There is no significant relationship between financial knowledge and financial behaviour of the working class of national capital region.

- $\mathrm{H}_{02}$ : There is no significant relationship between financial knowledge and financial attitude of the working class of national capital region.

- $\mathrm{H}_{03}$ : There is no significant relationship between financial behaviour and financial attitude of the working class of national capital region.

- $\mathrm{H}_{04}$ : There is no significant relationship between financial knowledge and financial literacy level of the working class of national capital region.

- $\mathrm{H}_{05}$ : There is no significant relationship between financial behaviour and financial literacy level of the working class of national capital region.

- $\mathrm{H}_{06}$ : There is no significant relationship between financial attitude and financial literacy level of the working class of national capital region.

\subsection{Practical and Social Implications}

- The Government or the policy maker should do more efforts to improve the level of financial attitude and financial behaviour to improve the level of financial literacy because significant difference has been found in the level of financial attitude and financial behaviour across some of the demographic factors.

- The increased financial literacy would be helpful in improving the saving and investment behaviour of the public which will lead to high capital formation to achieve the desired objective of economic growth. Consequently, more employment opportunities will increase the social security in the society.

\subsection{Literature Review}

The existing literature suggests that financial literacy has three most important dimensions. These are financial knowledge, financial behaviour and financial attitude and the study of Baron \& Kenny (1986) described that there is the relationship between financial attitude and behaviour, which is influenced by financial knowledge.

The study of Venkataraman et al. (2018) identified the factors that determine the financial literacy by using the confirmatory factor analysis. This study determined the four factors i.e. financial attitude, behavioural factor, financial knowledge and Influential factor based on 70 salaried working class of Bangalore. It showed that financial knowledge has a predictable coefficient of 0.27 and influential factor has a coefficient of 0.75 . There is a positive relationship among the behavioral factor, financial knowledge and influence factor while financial attitude has negative effect on financial literacy.

Edirisinghe, et al., (2017) found the correlation between financial literacy and financial behaviour of 223 undergraduate students of Sri Lanka. The sample was consisting of $39 \%$ of male students and $61 \%$ female students. They analyzed the data through correlation and regression techniques. The study found significant and positive correlation among financial behaviour and all the dimensions of financial literacy. The regression analysis indicated that all the dimensions like financial literacy on savings, investment, credit and insurance except money management have possessed positive and significant effect on financial behaviour of the management students.

Rahim, et al., (2016) examined the Islamic financial literacy and its determinants with a small sample of 200 students of University Utara (Malaysia). Where 58.5\% respondents were females and rest were the male students. It used eleven items but after applying factor analysis, these items reduced to seven only. The cumulative variance was $43.06 \%$ and values loading were found between 0.566 to 0.751 . The study found hopelessness, religiosity and financial satisfaction important determinants of Islamic financial literacy. Whereas, the religiosity found in Islamic financial literacy with highest variance followed by hopelessness and financial satisfaction respectively.

Similarly, the study of Gupta and Madan (2016) depicted that financial attitude, financial behaviour and financial knowledge are significantly positively correlated with the financial literacy score of 213 individuals. The finding reflected the poor level of financial knowledge on the basis of financial knowledge score along with low score of 
financial behaviour. The financial attitude supposed as an average attitude of respondents towards financial matters. There is an average financial literacy score of salaries women.

Bhushan, and Medury (2013) showed that financial literacy level of salaried individuals of Himachal Pradesh based on various demographic and socio-economic factors. Financial literacy gets affected by gender, education, income, nature of employment and place of work whereas it does not get affected by age and geographic region. Income of an individual is significantly related with the level of financial literacy. Economically weaker section particularly in youth has lack of financial knowledge. People who belongs to rich family has more financial knowledge. Level of financial literacy has been found positively related to income and earnings, it increases with the increase in income level.

Yong, et al. (2013) conducted a survey of 1915 young working adults between the ages of 18 to 40 of Malaysia, China and India and this data has been analyzed by using Partial Least Square (PLS) structural equation modelling (SEM). They found that financial education is a good predictor of financial knowledge. Further they found that financial knowledge has a considerable positive relationship with financial behaviour. However, financial behaviour has been significant negative relationship with financial literacy. They found that financial attitude partially mediates the relationship between financial knowledge and behaviour both way directly and indirectly. They did not found gender difference in any of the paths of the model and concluded that Chinese and Indians have highest level of financial knowledge, financial behaviour and also high financial attitude.

Sarah (2009) depicted that there is a significant and constructive relationship between financial knowledge and financial behaviour. Higher levels of education facilitate individuals to know finances better and hence improve on the way they financially behave. The study further stated that financial behaviour is controlled by locus of factors particularly individual financial circumstances and cultural values also has significant effect on the financial behaviour of the staff.

Hilgert, et al. (2003) focused on the relationship between financial knowledge and financial behavior through four factors of financial activity. These four factors are cash-flow management, credit management, saving and investment. The results reported positive and significant correlation between knowledge and behaviour across the range of finance activities.

\section{Research Design}

The research design gives the explanation of the procedure through which various objectives are achieved and hypotheses are tested. Further, it describes the scope of the study, sample design, data collection techniques and the technique through which the data is analyzed. The present research work is an exploratory-cum-descriptive research.

\subsection{Scope of the Study}

The current research work has covered the working class of schools/colleges, banks/financial Institutions employees, lawyers/legal professions, doctors/medical professionals, CA/CS/ICWAs, and other professionals like engineers and computer experts of National Capital Region. The present study has covered the major cities of National Capital Region of India like Delhi, Faridabad, Gurugram, Noida and Ghaziabad and the Delhi zone includes-North Delhi, South Delhi, West Delhi and East Delhi.

\subsection{Sample Design}

A sample design is the framework/structure that provides the basis for the selection of a sample survey from the target population by considering the time and money constraints. So, the sampling is the process to select the sample unit from the concern population to represents the target population. The sampling design can be simplest and it can be very complex. But here very simple method of sampling design has been opted. Because sampling method must be chosen on the basis of situation and circumstances under which research will be carried out and who will be the targeted respondents. Here the sample design has been explained by defining the sample unit, sampling techniques and sample size.

- Sample Size: The sample size was decided on the basis of reviewed literature. The targeted sample size was 600 and to attain this target more than 1500 respondents were contacted to fill up the questionnaires and this questionnaire was also circulated to more than 1000 contacts through internet. At last only 596 completely filled questionnaires were selected for analysis.

- Sample Unit: The sample unit consists of working class of schools/colleges, bank's/financial Institution's employees, lawyer/legal professionals, doctor/medical professionals and other professionals like 
CA/CS/ICWAs, engineers and computer experts. The respondents of up to the age of 25 year to 50 year and above, male and female, living in urban and rural area of National Capital Region of have been contacted.

- Sampling Method: To collect the sample size data random cum convenient sampling method has been used.

\subsection{Data Analysis Techniques}

This study is a descriptive research work based on sample size of 596 respondents of working class of national capital region of India. The data has been collected through a well-designed five point Likert scale questionnaire. The data has been analysed by applying the exploratory factor analysis followed by Varimax rotation in Stage 2. But, before applying the factor analysis KMO and Bartlett's test has been applied to check the sampling adequacy. Further, on the basis of generated factor's score, correlation analysis and multiple regressions analysis have been done. To know the dependency level of financial literacy on financial knowledge, financial behaviour and financial attitude the following multiple regression model has been fitted:

$$
\mathrm{FL}=\text { Constant }+\mathrm{b} 1 * \mathrm{FA}+\mathrm{b} 2 * \mathrm{FB}+\mathrm{b} 3 * \mathrm{FK}
$$

OR

Financial Literacy $=$ Constant + b1 Financial Attitude $+b 2$ Financial Behavior $+b 3$ Financial Knowledge

\section{Finding and Discussion}

\subsection{Determinants of Financial Literacy Through Exploratory Factor Analysis}

Before applying the factor analysis KMO and Bartlett's test have been applied to check the sampling adequacy. The KMO value should lies between 0.8 tol to show sampling adequacy and if it is less than 0.6 than it shows that the sample is not adequate and remedial action is required. If the KMO value is $\geq 0.7$ than it is treated as middling and if $\mathrm{KMO}$ values $\geq 0.8$ than it is treated as meritorious (Backhaus, et al., 2006). The current study found the value of the KMO (Kaiser-Meyer-Olkin Measure of Sampling Adequacy) test in the following manner:

$\mathrm{KMO}=0.702$ (70\% middling sampling adequacy of each variable in financial knowledge data)

$\mathrm{KMO}=0.846$ (85\% meritorious sampling adequacy of each variable in financial behaviour data)

$\mathrm{KMO}=0.793$ (79\% middling sampling adequacy of each variable in financial attitude data).

Table 1. KMO and Bartlett's Test and Reliability Statistics

\begin{tabular}{lccc}
\hline \multirow{2}{*}{ Factors } & \multirow{2}{*}{ KMO } & \multicolumn{2}{c}{ Bartlett's Test of Sphericity } \\
\cline { 3 - 4 } & & Approx. Chi-Square & Sig. \\
\hline Financial Knowledge & 0.702 & 659.200 & .000 \\
\hline Financial Behaviour & 0.846 & 1801.604 & .000 \\
\hline Financial Attitude & 0.793 & 1702.821 & .000 \\
\hline Reliability Statistics & & & No. of \\
\hline $\begin{array}{l}\text { Measurement Scale of Financial } \\
\text { Literacy }\end{array}$ & Cronbach's Alpha & $\begin{array}{c}\text { Cronbach's Alpha Based on } \\
\text { Standardized Items }\end{array}$ & 11 \\
\hline Financial knowledge & 0.623 & 0.657 & 13 \\
\hline Financial Behaviour & 0.823 & 0.826 & 14 \\
\hline Financial Attitude & 0.767 & 0.770 & \\
\hline
\end{tabular}

Source: Primary data based on questionnaire

The Table 1 shows that the KMO values are greater than 0.70 and therefore it reflects middling sampling adequacy for data sets of financial knowledge, financial behaviour and financial attitude. The p-value of the Bartlett's Sphericity Test has been found significant because $\mathrm{p}<.001$. It shows that data set is suitable for applying exploratory factor analysis. The Cronbach's Alpha value in table No. 1 explain the reliability level of the three data set of financial knowledge, financial behaviour and financial attitude and the acceptable Cronbach's Alpha value should be greater than 0.6(Hair et. al. 2006). The table 1 shows that Cronbach's Alpha value of all the statements of financial knowledge after Anti-Image analysis came out to be 0.623. It means reliability level is satisfactory. Similarly, Alpha 
value of all the variables of financial behaviour and financial attitude came out to be 0.823 and 0.767 respectively. It means the given data sets are reliable and valid for further analysis.

For further exploratory factor analysis, two criteria have been used to determine the factors: Firstly-Anti -Image correlation value should be greater than 0.6 (Backhaus et al., 2006). Secondly - to determine the numbers of factors K1 Rule or Kaiser (1960) rule has been followed that Eigen value must be greater than one.

Table 2. Factors analysis of financial knowledge

\begin{tabular}{|c|c|c|c|c|c|c|c|}
\hline Factors & $\begin{array}{l}\text { Variables/ } \\
\text { Statement }\end{array}$ & $\begin{array}{l}\text { Factor } \\
\text { Loading }\end{array}$ & Communality & $\begin{array}{l}\text { Statement } \\
\text { Mean }\end{array}$ & $\begin{array}{l}\text { Factor } \\
\text { Mean }\end{array}$ & $\begin{array}{l}\text { Factor } \\
\text { Eigen } \\
\text { Value }\end{array}$ & $\begin{array}{c}\text { Cumulative \%age } \\
\text { of Variance }\end{array}$ \\
\hline \multirow{4}{*}{ 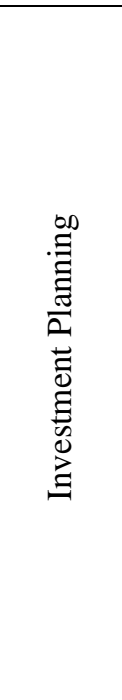 } & $\begin{array}{l}\text { 2. Financial plans should } \\
\text { take into account } \\
\text { possible changes in your } \\
\text { life }\end{array}$ & 0.670 & 0.508 & 3.66 & \multirow{4}{*}{3.73} & \multirow{4}{*}{2.421} & \multirow{4}{*}{22.0} \\
\hline & $\begin{array}{l}\text { 5. Before investing, it is } \\
\text { important to read and } \\
\text { understand the } \\
\text { Investment Statement } \\
\text { that explains details } \\
\text { about the investment }\end{array}$ & 0.709 & 0.508 & 3.85 & & & \\
\hline & $\begin{array}{l}\text { 6. An investment with a } \\
\text { high return is likely to } \\
\text { be at high risk }\end{array}$ & 0.679 & 0.558 & 3.80 & & & \\
\hline & $\begin{array}{l}\text { 7. High inflation means } \\
\text { that the cost of living is } \\
\text { increasing rapidly }\end{array}$ & 0.608 & 0.370 & 3.61 & & & \\
\hline \multirow{4}{*}{ 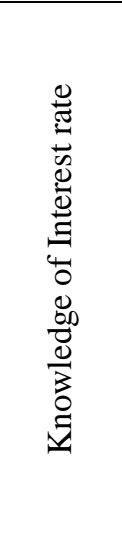 } & $\begin{array}{l}\text { 10. Interest rate on PPF } \\
\text { is equal to Fixed } \\
\text { Deposits }\end{array}$ & 0.621 & 0.390 & 3.01 & \multirow{4}{*}{3.36} & \multirow{4}{*}{1.482} & \multirow{4}{*}{35.5} \\
\hline & $\begin{array}{l}\text { 11. Interest rate on Short } \\
\text { term loans, Bonds are } \\
\text { generally high }\end{array}$ & 0.650 & 0.466 & 3.36 & & & \\
\hline & $\begin{array}{l}\text { 12. Interest rate on Tax } \\
\text { Exempted bonds is } \\
\text { generally low }\end{array}$ & 0.742 & 0.556 & 3.53 & & & \\
\hline & $\begin{array}{l}\text { 13. Interest rate on } \\
\text { Saving } \mathrm{A} / \mathrm{c} \text { is low } \& \\
\text { Current } \mathrm{A} / \mathrm{c} \text { is Nil }\end{array}$ & 0.559 & 0.337 & 3.55 & & & \\
\hline \multirow{2}{*}{ 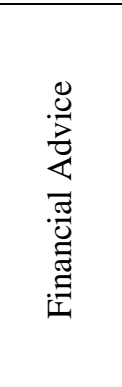 } & $\begin{array}{l}\text { 4. It is important to find } \\
\text { out how a financial } \\
\text { adviser is being paid }\end{array}$ & 0.687 & 0.601 & 3.57 & \multirow[b]{2}{*}{3,17} & \multirow[b]{2}{*}{1.113} & \multirow[b]{2}{*}{45.6} \\
\hline & $\begin{array}{l}\text { 8. It is usually possible } \\
\text { to reduce the risk of } \\
\text { investing in the stock } \\
\text { market by buying a wide } \\
\text { range of stocks and } \\
\text { shares. }\end{array}$ & 0.572 & 0.386 & 2.77 & & & \\
\hline
\end{tabular}

Source: Primary data based on questionnaire 
The Table 2 explains the variables factor loading, communality, mean of statements and factor mean, Eigen values and cumulative percentage of variance of the factors. But to determine the factor Anti -Image correlation value should be greater than 0.6 (Backhaus et al., 2006). For this data set except statement 1 and 3, all remaining statements have Anti-image correlation values in between 0.624 to 0.750 . Therefore, the Statement 1 and 3 were removed from the further analysis. From the data set of financial knowledge three determinants (factors) namely: investment planning, knowledge of interest rate and financial advice have been constituted. This table consists of only those factors that have Eigen value of greater than 1 . The value of communalities got more than 0.4 . These three factors namely Investment planning, knowledge of interest rate and financial advice has explained $45.60 \%$ variance of financial knowledge. Though this explained variance is slightly on lower side but it is acceptable because numbers of extracted factors are more than two (Osborne, J. W. (2014) page no. 40-41, Rahim, et. al., (2016) page no. 416)

Further, the table shows the results of rotated component matrix of financial knowledge variables to determine most common and closely correlated variables. The three factors which have Eigen value 1 or more than 1 have been considered for analysis. The first factor which is comprises of Statements No. 2, 5, 6 and 7, with 0.670, 0.709, 0.679 and 0.608 factors loading respectively. The factor loading explain that these statements are moderately correlated with the first factor named "Investment Planning" and this factor Eigen value has come out 2.421 and it contributes $22 \%$ variance of financial knowledge. It means $22 \%$ of financial knowledge is explained by the investment planning. Whereas, the second factor (knowledge of interest rates) is moderately correlated with the Statements No. 10, 11, 12 and 13, with $0.621,0.650,0.742$ and 0.559 factors loading respectively and this factor Eigen value has come out 1.482 and it explains $13.5 \%$ variance in the cumulative variance of financial knowledge. The third factor named as "Financial Advice" is correlated with the statements 4 and 8, which have 0.687 and 0.572 factor loading respectively. It extracted factor has 1.113 Eigen value with $10.1 \%$ variance in the cumulative variance of financial knowledge. It means $10 \%$ of the financial knowledge is depending on the financial advice from the expert and financial consultant. The respondents understand the importance of financial advisor because financial advisor generally suggest that risk can be reduced if investment is made in wide range of product. On the basis of this analysis it can be said that $45.6 \%$ cumulative variance of financial knowledge is explained by investment planning, knowledge of interest rates of financial products and financial advice to the individual by experts.

Table 3. Factor analysis of financial behaviour variables

\begin{tabular}{|c|c|c|c|c|c|c|c|}
\hline & $\begin{array}{l}\text { Variables/ } \\
\text { Statement }\end{array}$ & $\begin{array}{l}\text { Factor } \\
\text { Loading }\end{array}$ & Communality & $\begin{array}{c}\text { Statement } \\
\text { Mean }\end{array}$ & $\begin{array}{l}\text { Factor } \\
\text { Mean }\end{array}$ & $\begin{array}{l}\text { Factor } \\
\text { Eigen } \\
\text { Value }\end{array}$ & $\begin{array}{c}\text { Cumulative \%age } \\
\text { of Variance }\end{array}$ \\
\hline \multirow{4}{*}{ 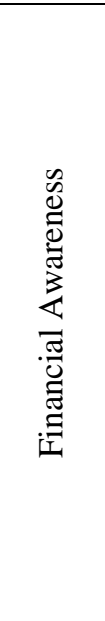 } & $\begin{array}{l}\text { 1. I am much organized } \\
\text { when it comes to } \\
\text { manage my money day } \\
\text { to day. }\end{array}$ & 0.841 & 0.720 & 3.61 & \multirow{4}{*}{3.74} & \multirow{4}{*}{4.074} & \multirow{4}{*}{37.1} \\
\hline & $\begin{array}{l}\text { 2. I keep a close } \\
\text { personal watch on my } \\
\text { financial affairs }\end{array}$ & 0.821 & 0.703 & 3.69 & & & \\
\hline & $\begin{array}{l}\text { 3. I set long term } \\
\text { financial goals and } \\
\text { strive to achieve them }\end{array}$ & 0.689 & 0.554 & 3.70 & & & \\
\hline & $\begin{array}{l}\text { 4. Before I buy } \\
\text { something I carefully } \\
\text { consider whether I can } \\
\text { afford it }\end{array}$ & 0.563 & 0.482 & 3.94 & & & \\
\hline \multirow{2}{*}{ 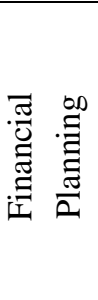 } & $\begin{array}{l}\text { 12. If I lost my job, I } \\
\text { will spend from my } \\
\text { saving }\end{array}$ & 0.813 & 0.402 & 3.70 & \multirow[b]{2}{*}{3.76} & \multirow[b]{2}{*}{1.281} & \multirow[b]{2}{*}{48.6} \\
\hline & $\begin{array}{l}\text { 13. During crisis, I } \\
\text { could get money from } \\
\text { my savings and } \\
\text { investments }\end{array}$ & 0.774 & 0.696 & 3.83 & & & \\
\hline
\end{tabular}




\begin{tabular}{|c|c|c|c|c|c|c|c|}
\hline & $\begin{array}{l}\text { 11. I make sure that I } \\
\text { have money to bear } \\
\text { expenses }\end{array}$ & 0.632 & 0.635 & 3.81 & & & \\
\hline & $\begin{array}{l}\text { 10. I consider various } \\
\text { products/loans/policies } \\
\text { from different } \\
\text { companies before } \\
\text { taking my decision }\end{array}$ & 0.541 & 0.528 & 3.69 & & & \\
\hline \multirow{2}{*}{ 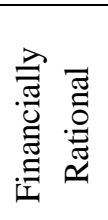 } & $\begin{array}{l}\text { 5. I prefer to buy things } \\
\text { on cash rather than on } \\
\text { credit }\end{array}$ & 0.825 & 0.378 & 3.86 & \multirow{2}{*}{3.96} & \multirow{2}{*}{1.003} & \multirow[b]{2}{*}{57.8} \\
\hline & $\begin{array}{l}\text { 6. I pay my bills on } \\
\text { time }\end{array}$ & 0.642 & 0.689 & 4.05 & & & \\
\hline
\end{tabular}

Source: Primary data based on questionnaire

The Table 3 depicts the results of factors analysis of financial behaviour. The three extracted factors have been named as: financial awareness, financial planning and financially rational. The anti-image correlation values of all the included items have been found in between 0.763 to 0.909 and the statements 8 and 9 have been excluded from the analysis because their anti-image correlation value were less than 0.6 .

The three factors which have Eigen value 1 or more than 1 have been considered for analysis. The Eigen value of factor 1 has been come out 4.074 and it explains $37 \%$ variance of the financial behaviour. Whereas, the factor- 2 has Eigen value 1.281 with $11.6 \%$ of variance and the third extracted factor has 1.003 Eigen value with $9.1 \%$ of variance. These three extracted factors explain $57.8 \%$ cumulative variance of financial behaviour which is relatively good (Osborne, J. W. (2014) page no. 38, Rahim, et. al., (2016) page no. 417).

The first factor of financial behaviour consists of Statements No. 1, 2, 3, 4 and 7, (Table 3) which have 0.841, 0.821, 0.6890 .563 and 0.630 factor loading respectively. These statements are highly correlated with the first factor, which has been named as "Financial Awareness". The second factor comprises of the statements 10, 11, 12, and 13, with factor loading $0.813,0.774,0.632$ and 0.541 respectively. These statements are related to the future financial planning. Therefore, this factor has been named as "Financial Planning" to manage future financial crisis. The third factor is associated with the statements 5 and 6 with factor loading 0.825 and 0.642 respectively. This factor has been named as "Financially Rational" because respondent of financially rational behaviour buy goods and services on cash rather than on credit and pay their bills on time.

Table 4. Factor analysis of financial attitude variables

\begin{tabular}{|c|c|c|c|c|c|c|c|}
\hline Factors & $\begin{array}{l}\text { Variables/ } \\
\text { Statement }\end{array}$ & $\begin{array}{l}\text { Factor } \\
\text { Loading }\end{array}$ & Communality & $\begin{array}{l}\text { Statement } \\
\text { Mean }\end{array}$ & $\begin{array}{l}\text { Factor } \\
\text { Mean }\end{array}$ & $\begin{array}{l}\text { Factor } \\
\text { Eigen } \\
\text { Value } \\
\end{array}$ & $\begin{array}{c}\text { Cumulative \%age } \\
\text { of Variance }\end{array}$ \\
\hline \multirow{5}{*}{ 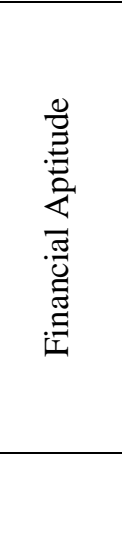 } & $\begin{array}{l}\text { 9. I feel confident about } \\
\text { my investment skills }\end{array}$ & 0.743 & 0.622 & 3.60 & \multirow{4}{*}{3.66} & \multirow{4}{*}{3.626} & \multirow{4}{*}{25.9} \\
\hline & $\begin{array}{l}10 . \text { I feel satisfied when I } \\
\text { think about planning my } \\
\text { retirement }\end{array}$ & 0.778 & 0.634 & 3.52 & & & \\
\hline & $\begin{array}{l}\text { 11. I am disciplined at } \\
\text { saving }\end{array}$ & 0.659 & 0.530 & 3.73 & & & \\
\hline & $\begin{array}{l}\text { 12. I get a lot of } \\
\text { satisfaction from saving } \\
\text { for the future }\end{array}$ & 0.653 & 0.511 & 3.78 & & & \\
\hline & $\begin{array}{l}15 . \text { I pay bills/EMIs } \\
\text { before the due date }\end{array}$ & 0.843 & 0.722 & 3.82 & 3.78 & 1.756 & 38.4 \\
\hline
\end{tabular}




\begin{tabular}{|c|c|c|c|c|c|c|c|}
\hline & $\begin{array}{l}\text { 14. I pay off credit card } \\
\text { payment on before due } \\
\text { date or on the due date }\end{array}$ & 0.801 & 0.660 & 3.74 & & & \\
\hline & $\begin{array}{l}\text { 13. I save money for my } \\
\text { children's bright future } \\
\text { / or for me }\end{array}$ & 0.636 & 0.532 & 3.78 & & & \\
\hline \multirow{5}{*}{ 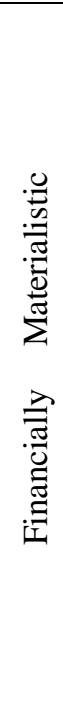 } & $\begin{array}{l}\text { 2. I find it more } \\
\text { satisfying to spend } \\
\text { money than to save it for } \\
\text { the future }\end{array}$ & 0.794 & 0.646 & 3.42 & \multirow{5}{*}{3.49} & \multirow{5}{*}{1.304} & \multirow{5}{*}{47.8} \\
\hline & $\begin{array}{l}\text { 5. Money is there to be } \\
\text { spent only }\end{array}$ & 0.679 & 0.477 & 3.14 & & & \\
\hline & $\begin{array}{l}\text { 4. I am prepared to take } \\
\text { risk when making an } \\
\text { investment }\end{array}$ & 0.590 & 0.383 & 3.65 & & & \\
\hline & $\begin{array}{l}\text { 1. I have enough time to } \\
\text { plan and review my } \\
\text { finance }\end{array}$ & 0.507 & 0.379 & 3.53 & & & \\
\hline & $\begin{array}{l}\text { 3. I am more focused on } \\
\text { day-to-day } \\
\text { responsibilities than on } \\
\text { retirement planning }\end{array}$ & 0.468 & 0.308 & 3.70 & & & \\
\hline \multirow{2}{*}{ 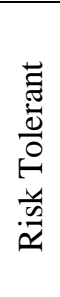 } & $\begin{array}{l}\text { 8. I have to be willing to } \\
\text { take substantial } \\
\text { investment risks for } \\
\text { retirement }\end{array}$ & 0.811 & 0.705 & 3.74 & \multirow{2}{*}{3.47} & \multirow{2}{*}{1.099} & \multirow{2}{*}{55.6} \\
\hline & $\begin{array}{l}\text { 7. I like to get financial } \\
\text { advice but then make my } \\
\text { own decision }\end{array}$ & 0.752 & 0.675 & 3.19 & & & \\
\hline
\end{tabular}

Source: Primary data based on questionnaire

The Table 4 describes the outcome of factor analysis of financial attitude. After applying the Principle Component Method of factor analysis four factors have been extracted, which have been named as: financial aptitude, financial discipline, financially materialistic and risk tolerant. These factors diagonally showed values in the anti-image correlation matrix in between 0.607 to 0.868 but the Statement- 6 value has been found less than 0.6 . Therefore, this statement was removed from the anti-image correlation analysis. The Table 4 consists of only those factors which have Eigen value greater than 1. The Eigen value of first factor come out to be 3.626 and it explain $25.9 \%$ of variance, whereas Eigen value of factor- 2 has been noted 1.756 with $12.5 \%$ of variance, further Eigen value of factor-3 come out 1.304 with $9.3 \%$ of variance and at last the fourth factor's Eigen value come out 1.099 with $7.9 \%$ of variance. These four factors explain $55.60 \%$ cumulative variance of financial attitude.

The first factor of financial attitude is highly correlated with the Statements $9,10,11 \& 12$ which have $0.742,0.778$, 0.659 and 0.653 factors loading respectively. These statements reflect the "Financial Aptitude" of the respondents. Such respondents have high confidence on their investments skills, satisfied about their retirement planning and they are disciplined saver. The second factor composed of Statements 15, 14 and 13 which have loading of $0.843,0.801$ and 0.636 respectively. The second factor has been named as "Financial Discipline" because such respondents pay their bills/ EMI before the due dates, pay credit card payments before or on due dates and save money for their children and for themselves. The third factor composed of Statements No. 2, 5, 4, 1, and 3 with 0.794, 0.679, 0.590, 0.507 and 0.468 factor loading respectively. These five statements reflect the "Financially Materialistic" attitude of the respondents. Such people get more satisfaction by spending money than to save it for the future because they think that money is to spend. Such people can take risk, as they think that they have enough time to review their financial plan. These people are usually more focused on day-to-day responsibilities than on retirement planning. 


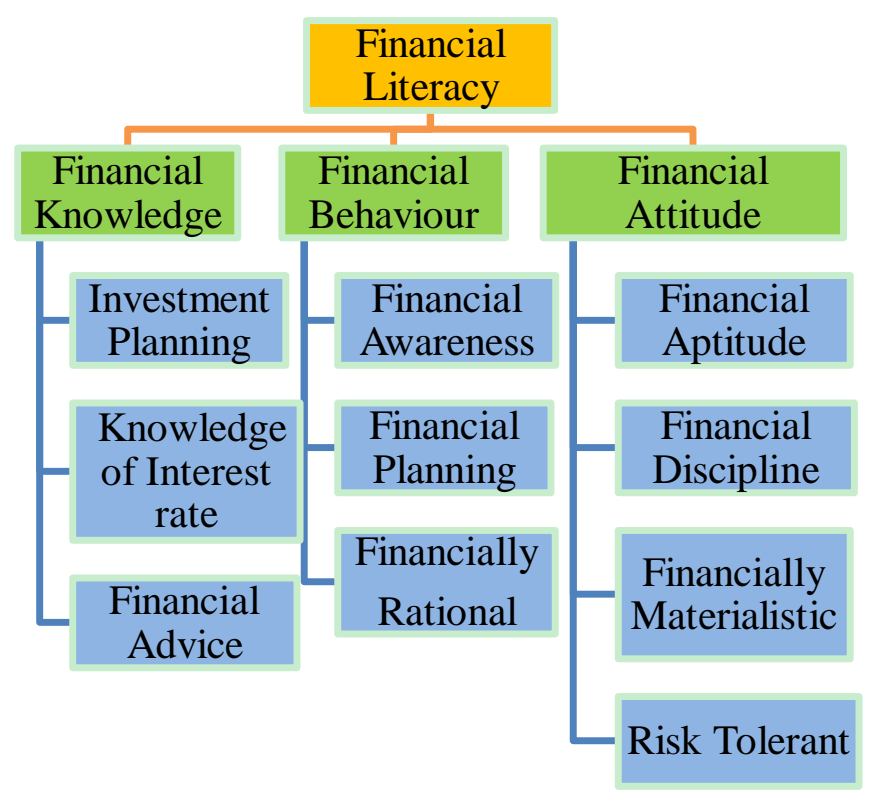

Figure 1. Determinants of financial literacy (Based on factor analysis)

Source: Primary data based on questionnaire

The last fourth factor composed of Statements 7 and 8, which have 0.811 and 0.752 factor loading respectively. The people who are willing to take substantial investment risk for retirement and who like to take advice but make their own decision are called Risk tolerant respondents. Therefore, the fourth factor has been named "Risk Tolerant". It reflects the risk taking financial attitude of the respondents. Figure 1 gives the bird's eye view of the all determinants of $\mathrm{f}$ financial literacy.

\section{Relationship Between Various Dimensions of Financial Literacy}

The Table- 5 shows the intra correlation between factors of financial knowledge, financial behaviour and financial attitude. The factor named "Investment Planning" has less notable positive correlation with factors named "Knowledge of Interest Rates" and notable but low positive linear correlation with the factors like financial awareness, financial planning, financial rationality, financial aptitude, financial materialistic and risk tolerant at 5\% level of significance. Whereas, the factor named "knowledge of interest rates" has very low positive association with financial aptitude and has very mild but significant positive association with risk tolerant at $5 \%$ level of significance. The factor named financial advice has notable significant negative correlation with the factors like financial awareness, financial planning, financial aptitude and financial discipline but it has mild negative significant correlation with financial materialistic and risk tolerant at 5\% significance level. Because higher the cost of financial adviser lower is the tendency to seek financial advice and this tendency can reduce the financial awareness, disturb the financial planning, aptitude and discipline of the working people because the working class has limited income.

Table 5. Correlation among factors of financial knowledge, financial behaviour and financial attitude

\begin{tabular}{|c|c|c|c|c|c|c|c|c|c|c|}
\hline \multirow[b]{2}{*}{ Factors } & \multicolumn{3}{|c|}{$\begin{array}{l}\text { Factors of Financial } \\
\text { Knowledge }\end{array}$} & \multicolumn{3}{|c|}{$\begin{array}{c}\text { Factors of Financial } \\
\text { Behaviour }\end{array}$} & \multicolumn{4}{|c|}{ Factors of Financial Attitude } \\
\hline & 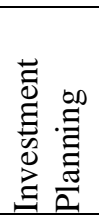 & 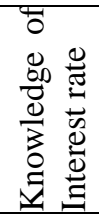 & 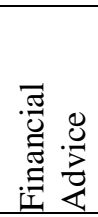 & 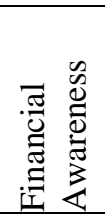 & 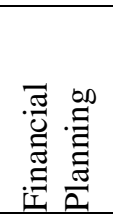 & 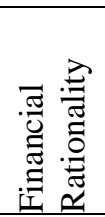 & 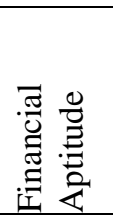 & 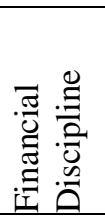 & 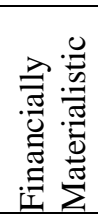 & 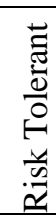 \\
\hline $\begin{array}{ll}\text { Factors of } & \text { Investment } \\
\text { Financial } & \text { Planning }\end{array}$ & & & & & & & & & & \\
\hline
\end{tabular}




\begin{tabular}{|c|c|c|c|c|c|c|c|c|c|c|}
\hline \multirow[t]{2}{*}{ Knowledge } & $\begin{array}{l}\text { Knowledge of } \\
\text { Interest rate }\end{array}$ & $.099 * *$ & & & & & & & & \\
\hline & $\begin{array}{l}\text { Financial } \\
\text { Advice }\end{array}$ & -0.19 & .052 & & & & & & & \\
\hline \multirow{3}{*}{$\begin{array}{l}\text { Factors of } \\
\text { Financial } \\
\text { Behaviour }\end{array}$} & $\begin{array}{l}\text { Financial } \\
\text { Awareness }\end{array}$ & $.181 *$ & .055 & $-.134 *$ & & & & & & \\
\hline & $\begin{array}{l}\text { Financial } \\
\text { Planning }\end{array}$ & $.157 *$ & .042 & $-.142 *$ & $.456^{*}$ & & & & & \\
\hline & $\begin{array}{l}\text { Financial } \\
\text { Rationality }\end{array}$ & $.149 *$ & -.142 & -.074 & $.414 *$ & $.359^{*}$ & & & & \\
\hline \multirow{4}{*}{$\begin{array}{l}\text { Factors of } \\
\text { Financial } \\
\text { Attitude }\end{array}$} & $\begin{array}{l}\text { Financial } \\
\text { Aptitude }\end{array}$ & $.140^{*}$ & $.132 *$ & $-.115^{*}$ & $.373 *$ & $.320 *$ & $.205 *$ & & & \\
\hline & $\begin{array}{l}\text { Financial } \\
\text { Discipline }\end{array}$ & .024 & .019 & $-.184 *$ & $.199 *$ & $.177 *$ & -.001 & $.381 *$ & & \\
\hline & $\begin{array}{l}\text { Financially } \\
\text { Materialistic }\end{array}$ & $.141 *$ & .043 & -.061 & $.326^{*}$ & $.298 *$ & $.318 *$ & $.342 *$ & $.131 *$ & \\
\hline & Risk Tolerant & $.135^{*}$ & $.094 * *$ & -.066 & $.179 *$ & $.176^{*}$ & $.212 *$ & $.299 *$ & $.234 *$ & $.238^{*}$ \\
\hline
\end{tabular}

*Correlation is significant at the 0.01 level (2-tailed), ${ }^{* *} 0.05$ level (2-tailed), Source: Primary Data based on questionnaire

The factor financial awareness has notable significant positive correlation with factors like financial planning (.456), financial rationality (.414), financial aptitude (.373) and financially materialistic (.326) at 5\% level of significance. Whereas it has less notable significant positive association with factors like financial discipline (.199) and risk tolerant (.177) at 5\% level of significant. Similarly, financial planning has notable significant positive correlation with financial rationality (.359), financial aptitude (.320) and financially materialistic (.298) at 5\% level of significance. In a same manner financial rationality has also considerable significant positive correlation with financial aptitude (.205), financially materialistic (.318) and risk tolerant (.212) at 5\% level of significance. The factor financial aptitude has also been found significantly positively associated with financial discipline (.381), financially materialistic (.342) and risk tolerant (.294) at 5\% level of significance. On the basis of this it can be concluded that factors of financial behaviour and financial attitude have more significant positive correlation in comparison to the factors of financial knowledge.

\subsection{Correlation Between Financial Knowledge, Financial Behaviour and Financial Attitude With Financial Literacy}

The Table 6 demonstrates the correlation between financial literacy and its various dimensions such as financial knowledge, financial behaviour and financial attitude. There is a positive but very low correlation $(0.030)$ between financial knowledge and financial behaviour as the p-value has been found more than 0.05 . Therefore, the Null hypothesis $\left(\mathrm{H}_{01}\right)$ has been accepted here that there is no significant relationship between financial knowledge and financial behaviour of working class. Although one of the factors of financial knowledge named "Investment Planning" has significant positive correlation with all the factors of financial behaviour (See Table 5).

The Null hypothesis $\left(\mathrm{H}_{02}\right)$ that there is no significant relationship between financial knowledge and financial attitude of working class has been accepted here. As, there is a positive correlation (0.056) between financial knowledge and financial attitude but the p-value has been found more than 0.05 . Therefore, it can be said that there is no significant relationship between financial knowledge and financial attitude of working class. Although, one of the factors of financial knowledge named "Investment Planning" has significant positive correlation with the factors of financial attitude (See Table 5). But the composite score of financial behaviour and financial attitude shows insignificant positive correlation. It means that financial attitude is independent from financial knowledge. On the basis of this conclusion it can be said that a person with high/low level of financial knowledge can have negative/positive financial attitude. 
Table 6. Correlation between financial knowledge, financial behaviour and financial attitude with financial literacy

\begin{tabular}{lcccc}
\hline \multicolumn{1}{c}{ Factors } & $\begin{array}{c}\text { Financial } \\
\text { Literacy }\end{array}$ & $\begin{array}{c}\text { Financial } \\
\text { Knowledge }\end{array}$ & $\begin{array}{c}\text { Financial } \\
\text { Behaviour }\end{array}$ & $\begin{array}{c}\text { Financial } \\
\text { Attitude }\end{array}$ \\
\hline Financial Literacy & 1 & & & \\
\hline Financial Knowledge & $.405^{*}$ & 1 & & \\
\hline Financial Behaviour & $.767^{*}$ & .030 & 1 & \\
\hline Financial Attitude & $.816^{*}$ & .056 & $.440^{*}$ & 1 \\
\hline
\end{tabular}

* Correlation is significant at the 0.01 level (2-tailed), Source: Primary Data based on questionnaire

Table 7. Results of the Null hypotheses

\begin{tabular}{lll}
\hline $\begin{array}{l}\text { Null hypothesis } \\
\text { No. }\end{array}$ & \multicolumn{1}{c}{ Null hypothesis Statements } & Results \\
\hline $\mathrm{H}_{01}$ & $\begin{array}{l}\text { There is no significant relationship between financial knowledge and financial } \\
\text { behaviour of the working class of national capital region. }\end{array}$ & Accepted \\
\hline $\mathrm{H}_{02}$ & $\begin{array}{l}\text { There is no significant relationship between financial knowledge and financial } \\
\text { attitude of the working class of national capital region }\end{array}$ & Accepted \\
\hline $\mathrm{H}_{03}$ & $\begin{array}{l}\text { There is no significant relationship between financial behaviour and financial } \\
\text { attitude of the working class of national capital region. }\end{array}$ & Rejected \\
\hline $\mathrm{H}_{04}$ & $\begin{array}{l}\text { There is no significant relationship between financial knowledge and financial } \\
\text { literacy level of the working class of national capital region }\end{array}$ & Rejected \\
\hline $\mathrm{H}_{05}$ & $\begin{array}{l}\text { There is no significant relationship between financial behaviour and financial } \\
\text { literacy level of the working class of national capital region }\end{array}$ & Rejected \\
\hline $\mathrm{H}_{06}$ & $\begin{array}{l}\text { There is no significant relationship between financial attitude and financial } \\
\text { literacy level of the working class of national capital region. }\end{array}$ & Rejected \\
\hline
\end{tabular}

Source: Based on Table 6.

The Null hypothesis $\left(\mathrm{H}_{03}\right)$ that there is no significant relationship between financial behaviour and financial attitude of working class has been rejected here because there is a significant positive correlation (0.440) between financial behaviour and financial attitude at $1 \%$ level of significance, as the p-value has been found less than 0.01 . It reflects that there is direct association between financial behaviour and financial attitude. It means that positive attitude of individual has positive effect on the financial behaviour of the individual and vice-versa.

The Null hypothesis $\left(\mathrm{H}_{04}\right)$ that there is no significant relationship between Financial Knowledge and Financial Literacy score of the working class of national capital region has been rejected here. As there is a positive correlation $(0.405)$ at $1 \%(.000)$ level of significant between the financial knowledge and the level of financial literacy. It reflects that the positive financial knowledge has significant positive effect on the level of financial literacy.

The Null hypothesis $\left(\mathrm{H}_{05}\right)$ that there is no significant relationship between financial behaviour and financial literacy level of the working class of national capital region has been rejected because a highly notable positive correlation (0.767) has been found between financial behaviour and the level of financial literacy at 1\% (.000) level of significance. It indicates that the very high positive financial behaviour can lead to increase in the level of financial literacy. The relationship between financial behaviour and financial attitude has also found significantly positive $(0.440)$ at $1 \%(.000)$ level of significance.

The Null hypothesis $\left(\mathrm{H}_{06}\right)$ that there is no significant relationship between financial attitude and level of financial literacy of the working class of national capital region has been rejected once again because a very high positive correlation (0.816) has been found between the financial attitude and the level of financial literacy at $1 \%(.000)$ level of significance. It indicates that the very high positive financial attitude can directly boost the level of financial literacy. It suggests that Government and banking/financial institutions should focus on improving the financial behaviour and financial attitude of the individual to improve the level of financial literacy. 
The relationship of financial attitude with financial knowledge is positive but very low and correlation with financial behaviour is moderately positive. To determine the absence of multi-Collinearity problems, the Pearson's correlation coefficients were tested. If the correlation coefficient between explanatory variables is greater than or equal to 0.9, then multi-Collinearity shall be considered as a serious problem (Kennedy, 1985, Andy Field, 2009). As shown in Table 5 and 6 the correlation coefficients between explanatory variables have not been found high and lying in between 0.030 to 0.816 . Therefore, it can be said that Multi-Collinearity problem is not a matter of concern in this case. These results depict that the financial knowledge, financial behaviour and financial attitude lead to boost the financial literacy level of the respondents. The study of Gupta and Madan (2016) also depicted that financial attitude, financial behaviour and financial knowledge are significantly positively correlated with the financial literacy score of an individual.

\section{Regression Analysis}

The Table 6 shows the significant notable association between financial literacy, financial attitude, financial behaviour and financial knowledge. Therefore, it becomes necessary to know the dependence level of financial literacy on the financial attitude, financial behaviour and financial knowledge. To test the dependency level of financial literacy or to know the good predictor of financial literacy, the following multiple regression model has been formulated:

$$
\mathrm{FL}=\mathrm{Constant}+\mathrm{b} 1 * \mathrm{FA}+\mathrm{b} 2 * \mathrm{FB}+\mathrm{b} 3 * \mathrm{FK}
$$

Where,

FL= Financial Literacy, FA= Financial Attitude, FB= Financial Behavior, FK=Financial Knowledge.

The goodness-of-fit of the above formulated regression model has been checked by the value of $\mathrm{R}$ square. The $\mathrm{R}$-square is statistical measure to check how close the data is with the fitted regression line. It shows the percentage of the variance explained by the independent variable in the linear regression model. To test the goodness-of-fit of model and for framing a linear regression model following hypotheses have been formulated:

- $\mathrm{H}_{07}$ : $\mathrm{R}$ square $=0$ (Variation given by three independent variables in Financial Literacy is equal to Zero)

- $\mathrm{H}_{08}$ : The coefficient of Financial Attitude is equal to zero $\left(b_{1}=0\right)$.

- $\mathrm{H}_{09}$ : The coefficient of Financial Behaviour is equal to zero $\left(b_{2}=0\right)$.

- $\mathrm{H}_{010}$ : The coefficient of Financial Knowledge is equal to zero $\left(b_{3}=0\right)$.

The Table 8 shows $\mathrm{R}$ value and the $\mathrm{R}$ value in the Model-1 has been found 0.816 which represents correlation between financial attitude and financial literacy. The $\mathrm{R}$ square is 0.666 and the adjusted $\mathrm{R}$ square is near to $\mathrm{R}$ square which means $66 \%$ variance in financial literacy is explained by financial attitude. In the Model- 2 the value of $\mathrm{R}$ has been found 0.934 , which shows the multiple correlation between two variables i.e., financial attitude and financial behaviour. The values of $\mathrm{R}$ square and adjusted $\mathrm{R}$-square have been found 0.873 and 0.872 respectively. It shows that $87 \%$ variance in financial literacy is explained by the two predictor variable i.e. financial attitude and financial behaviour. In the Model-3 the value of $\mathrm{R}$ has been found 0.981, which shows the multiple correlations between all variables i.e., financial attitude, financial behaviour and financial knowledge with financial literacy and the Value of $\mathrm{R}$ square and adjusted $\mathrm{R}$ square has been found same i.e. 0.963 . The adjusted $\mathrm{R}$ square give the value of 0.963 which close square to the R square, hence the model is well generalized. It revealed that $96 \%$ of the variance is being explained by the financial attitude, financial behaviour and financial knowledge. Means $96 \%$ level of financial literacy is explained by these three predictors.

The significance of $\mathrm{R}$ square is tested by using the $\mathrm{F}$ ratio. The changes in the amount of variance that can be explained results into F ratio of 1444.524 which is also significant $(\mathrm{p}<0.001)$. Therefore, it is enough evidence to reject the Null hypothesis $\left(\mathrm{H}_{07)}\right.$ that Variation given by three independent variables in Financial Literacy is equal to Zero $(\mathrm{R}$ square $=0)$ 
Table 8. Model summary

\begin{tabular}{|c|c|c|c|c|c|c|c|c|c|c|}
\hline \multirow[t]{2}{*}{ Model } & \multirow[t]{2}{*}{$\mathrm{R}$} & \multirow[t]{2}{*}{ R Square } & \multirow{2}{*}{$\begin{array}{l}\text { Adjusted R } \\
\text { Square }\end{array}$} & \multirow{2}{*}{$\begin{array}{l}\text { Std. Error of } \\
\text { the Estimate }\end{array}$} & \multicolumn{5}{|c|}{ Change Statistics } & \multirow{2}{*}{$\begin{array}{c}\text { Durbin-W } \\
\text { atson }\end{array}$} \\
\hline & & & & & $\begin{array}{c}\text { R Square } \\
\text { Change }\end{array}$ & F Change & df1 & df2 & $\begin{array}{l}\text { Sig. F } \\
\text { Change }\end{array}$ & \\
\hline 1 & $.816^{\mathrm{a}}$ & .666 & .665 & 2.02652 & .666 & 1181.899 & 1 & 594 & .000 & \\
\hline 2 & $.934^{\mathrm{b}}$ & .873 & .872 & 1.25210 & .207 & 963.016 & 1 & 593 & .000 & \\
\hline 3 & $.981^{\mathrm{c}}$ & .963 & .963 & 0.67565 & .090 & 1444.524 & 1 & 592 & .000 & 1.815 \\
\hline
\end{tabular}

a. Predictors: (Constant), FA, b. Predictors: (Constant), FA, FB, c. Predictors: (Constant), FA, FB, FK d. Dependent Variable: FL

Source: Primary data based on questionnaire

The Durbin-Watson statistic's value is (1.815) also a good indicator of assumption of whether the independent errors are acceptable or not. The Durbin-Watson value range between 1.5 to 2.5 is considered relatively normal correlation and if values are found less than 1 or more than 3 than there is serious correlation and definite cause of concern (Field, 2009). In the present case this value has been found 1.815, which means there is normal correlation.

\subsection{Multiple Regression Model}

In table 9 the model-3 shows 1.024 coefficient(Unstandardized Coefficient b1) for financial attitude and which has been found significant, thus Null hypothesis $\left(\mathrm{H}_{08}\right)$ has been rejected that the coefficient of Financial Attitude is equal to zero (b1=0). The coefficient of Financial Behaviour (b2) has also been found 1.013 and it is also significant. Therefore, the Null hypothesis $\left(\mathrm{H}_{09}\right)$ that the coefficient of Financial Behaviour is equal to zero $(b 2=0)$ is rejected. The Financial knowledge (b3) has a coefficient of 0.860 which is also significant. Thus, Null hypothesis $\left(\mathrm{H}_{010)}\right)$ that the coefficient of Financial Knowledge is equal to zero $\left(b_{3}=0\right)$ is rejected.

Each of beta (b-values) associated with standard error indicates that up to what extent these values would vary across different samples and these standard errors are used to determine whether or not the b-values differs significantly from zero. A t-statistics has been derived to tests whether b-value is significantly different from zero. Therefore, if the $t$-test associated with $b$-value is found significant then the predictor is creating significant contribution to the model. In the model, the Financial Attitude $\left(b_{1}\right)$ FA has a $b$-value $\left(b_{1}\right) 1.024(t=66.757$, $p$-value $=0.000)$, Financial Behaviour $\left(b_{2}\right)$ FB has a $b$-value $\left(b_{2}\right) 1.013(t=57.998$, $p$-value $=0.000)$, Financial Knowledge $\left(b_{3}\right)$ FK has a $b$-value $\left(b_{3}\right)$ $0.860(\mathrm{t}=38.007$, $\mathrm{p}$-value $=0.000)$.

Table 9. Coefficients

\begin{tabular}{|c|c|c|c|c|c|c|c|c|}
\hline & \multirow[t]{3}{*}{ Model } & \multicolumn{2}{|c|}{ Unstandardized Coefficients } & \multirow{3}{*}{$\begin{array}{c}\begin{array}{c}\text { Standardized } \\
\text { Coefficients }\end{array} \\
\text { Beta }(\beta)\end{array}$} & \multirow{3}{*}{$\mathrm{T}$} & \multirow{3}{*}{ Sig. } & \multicolumn{2}{|c|}{$\begin{array}{l}95 \% \text { Confidence } \\
\text { Interval for B }\end{array}$} \\
\hline & & $\mathrm{P}$ & Std Frror & & & & Lower & Upper \\
\hline & & D & Sta. EIIOI & & & & Bound & Bound \\
\hline \multirow[t]{2}{*}{1} & (Constant) & 15.041 & 0.598 & & 25.139 & .000 & 13.866 & 16.217 \\
\hline & FA & 1.421 & 0.041 & 0.816 & 34.379 & .000 & 1.340 & 1.502 \\
\hline \multirow[t]{3}{*}{2} & (Constant) & 9.103 & 0.416 & & 21.868 & .000 & 8.285 & 9.920 \\
\hline & FA & 1.033 & 0.028 & 0.593 & 36.335 & .000 & 0.977 & 1.089 \\
\hline & FB & 1.005 & 0.032 & 0.507 & 31.032 & . 000 & 0.941 & 1.068 \\
\hline \multirow[t]{4}{*}{3} & (Constant) & .990 & 0.310 & & 3.193 & .001 & 0.381 & 1.598 \\
\hline & FA & 1.024 & 0.015 & 0.588 & 66.757 & .000 & 0.994 & 1.054 \\
\hline & FB & 1.013 & 0.017 & 0.511 & 57.998 & .000 & 0.979 & 1.048 \\
\hline & FK & 0.860 & 0.023 & 0.301 & 38.007 & .000 & 0.816 & 0.905 \\
\hline
\end{tabular}

a. Dependent Variable: FL, Source: Primary Data based on questionnaire

As per the t-test values and $\mathrm{p}$-values $(\mathrm{p}<0.001)$, all the coefficients of predictors have been found highly significant. Therefore, it can be established that financial attitude, financial behaviour and financial knowledge are the good predictors to explain the level of financial literacy. 
The relevant model for the research would take the following form:

$$
\mathrm{FL}=\text { constant }+\mathrm{b} 1 * \mathrm{FA}+\mathrm{b} 2 * \mathrm{FB}+\mathrm{b} 3 * \mathrm{FK}
$$

Financial Literacy $=0.990+1.024$ Financial Attitude +1.013 Financial Behavior +0.860 Financial Knowledge

Table 10. Multiple Regression Model

\begin{tabular}{lccc}
\hline \multicolumn{1}{c}{ Model } & Coefficients $(\beta)$ & Std. Error & $\beta$ \\
\hline (Constant) & .990 & 0.310 & 0.588 \\
\hline Financial Attitude & 1.024 & 0.015 & 0.511 \\
\hline Financial Behaviour & 1.013 & 0.017 & 0.301 \\
\hline Financial Knowledge & 0.860 & 0.023 & \\
\hline
\end{tabular}

Source: Primary Data based on questionnaire

The Table 10 shows the relationship between predictors and dependent variable (Financial Literacy). It means that at one percent change in Financial Attitude score, the Financial Literacy would increase by 1.024 point by keeping other two variables constant. Similarly, for one-point change in Financial Behaviour and Financial Knowledge, the Financial Literacy score will increase by 1.013 and 0.860 points respectively, by keeping other two variables constant at a time. Thus all the three variables are having positive impact on financial literacy of the respondents. But the contribution of financial attitude has been found highest in defining the financial literacy among the working class and it is followed by financial behaviour and financial knowledge. It means, financial attitude and financial behaviour is better estimator of financial literacy in comparison to the financial knowledge, whereas the level of financial knowledge across various demographic factors has been found more or less same. Therefore, government or the policy maker should do more efforts to improve the level of financial attitude and financial behaviour because significant difference has been found in the level of financial attitude and financial behaviour across some of the demographic factors.

\section{Conclusion}

On the basis of this study it can be concluded that financial knowledge level can be judged by analyzing the investment planning of the individual, knowledge level of individual about interest rates on different financial product and tendency of individual to approach financial advisers. Financial behaviour of the people is judged by the level of financial awareness about the banking and financial system. Another important determinant of financial behaviour is financial planning of individual to manage the future financial needs and crisis. Some people, who are very financially rational, used to buy goods on cash basis rather than on credit. The financial attitude of the individual can be analyzed by assessing the financial aptitude of the individual who have high confidence on their investment skills and retirement planning. The financial discipline of the individual also decides the financial attitude of the individual. There are some people who do not bother about saving and investment. Such people have financially materialistic attitude. There are also some people, who ready to take substantial degree of risk. Such people have risk tolerant attitude.

As this study is an attempt to know the relationship between determinants and dimensions of financial literacy and to establish the dependency level of financial literacy on financial attitude, financial behaviour and financial knowledge. At last it is concluded here that there is no significant relationship between financial knowledge and financial behaviour of working class. And also there is no significant relationship between financial knowledge and financial attitude. It means that financial attitude is independent from financial knowledge and it can be said that a person with high/low level of financial knowledge can have negative/positive financial attitude.

Further, a direct association has been found between financial behaviour and financial attitude. It means that individual positive attitude has positive effect on the financial behaviour of the individual and vice-versa. At last financial literacy has been found to be significantly positively correlated with financial knowledge, financial behaviour and financial attitude. The relationship between financial behaviour and financial attitude has also found significantly positively correlated. It indicates that the very high positive financial attitude can directly boost the level of financial literacy. Last but not least it has been established that financial attitude, financial behaviour and financial knowledge are the good predictors to explain the level of financial literacy. Therefore, Government and banking/financial institutions should concentrate on the methods through which financial behaviour and financial attitude of the working class can be improving because the level of financial knowledge has been found insignificantly different across different working class groups. On the basis of this conclusion, further research can 
be conducted to confirm these determinants and relationship between financial knowledge, financial behaviour and financial attitude of the financial literacy.

\section{Acknowledgement}

This research work has been fully financed by University Grant Commission (UGC) of India. As Ms. Poonam was awarded with research fellowship of UGC and to fulfill this research work she joined Haryana School of Business of Guru Jambheshawar University of Science and Technology-Hisar (India). Therefore, we thank and acknowledge the contribution of UGC and Guru Jambheshawar University of Science and Technology (Hisar) for providing the financial, technical and infrastructural support. We also extend sincere thanks to all the researchers and institutions whose literatures have been quoted in completion of this research.

\section{References}

Backhaus, K., Erichson, B., Plinke, W., \& Weiber, R. (2006). Multivariate analysis: an application-oriented introduction. Springer Verlag, Berlin, 11(1), 543-601.

Bhushan, P., \& Medury, Y. (2014). An empirical analysis of inter linkages between financial attitudes, financial behaviour and financial knowledge of salaried individuals. Indian Journal of Commerce \& Management Studies, 3, 58-64.

Edirisinghe, U. C., Keerthipala, Y. M. S., \& Amarasinghe, A. R. (2017). Financial literacy and financial behavior of management undergraduates of Sri Lanka. International Journal of Management and Applied Science, 7(3), 1-6.

Field, A. P. (2009). Discovering statistics using SPSS and sex and drugs and rock ' $n$ ' roll. Sage Publication, London.

Gupta, J., \& Madan, M. (2016). An empirical study on financial literacy level of salaried females in digital era. Business Analyst, 37(1), 217-230.

Hair, J., Black, W., Babin, B., Anderson, R., \& Tatham, R. (2006). Multivariate data Analysis (6th ed.). New Jersey: Pearson Educational, Inc.

Hilgert, M., Hogarth, J., \& Beverley, S. (2003). Household financial management: the connection between knowledge and behavior, Technical report. Federal Reserve Bulletin.

Huston, J. S. (2010). Measuring financial literacy. The Journal of Consumer Affairs, 44(2), 296-316.

Kaiser, H. F. (1960). The Application of electronic computers to factor analysis. Educational and Psychological Management, 20, 141-151.

Kennedy, P. (1985). A Guide to Econometrics (2nd ed.). MIT Press, Cambridge, MA.

OECD. (2005). Improving financial literacy: analysis of issues and policie. https://doi.org/10.1787/fmt-v2005-art11-en

Osborne, J. W. (2014). Best Practices in Exploratory Factor Analysis. Scotts Valley, CA: CreateSpace independent Publishing. Retrieved from http://www.amazon.com/-/e/B00FCLJQES

Rahim, S. H. A., Rashid, R. A., \& Hamed, A. B. (2016). Factor analysis of Islamic financial literacy and its determinants: a pilot study. ISSC 2016 International Conference on Soft Science, pp. 413-418. https://doi.org/10.15405/epsbs.2016.08.58

Sarah, N. (2009). Financial knowledge locus of control cultural values and financial behaviour among new vision employees. Unpublished master dissertation. University Kampala Buganda.

Venkataraman, R., \& Venkatesan, Th. (2018). Analysis of factors determining financial literacy using structural equation modelling, SDMIMD Journal of Management, 9(1). 19-29.

Vitt, L. A., Anderson, C., Kent, J., Lyter, D. M., Siegenthaler, J. K., \& Ward, J. (2000). Personal finance and the rush to competence: financial literacy education. U.S. middleburg VA, Institute for Socio-Financial Studies.

Yong, C. C., Yew, S. Y., \& Wee, C. K. (2013). Financial knowledge, attitude and behaviour of young working adults in Malaysia. Institutions and Economies, 10(4), 21-48.

\section{Copyrights}

Copyright for this article is retained by the author(s), with first publication rights granted to the journal.

This is an open-access article distributed under the terms and conditions of the Creative Commons Attribution license (http://creativecommons.org/licenses/by/4.0/). 